\title{
ARTICLE Effects of Deep Freezing Temperature for Long-term Storage on Quality Characteristics and Freshness of Lamb Meat
}

OPEN ACCESS

$\begin{array}{ll}\text { Received } & \text { July 2, } 2018 \\ \text { Revised } & \text { August 1, 2018 } \\ \text { Accepted } & \text { August 1, 2018 }\end{array}$

*Corresponding author: Geun-Pyo Hong Department of Food Science and

Biotechnology, Sejong University, Seoul 05006, Korea

Tel: $+82-2-3408-2914$

Fax: $+82-2-3408-4319$

E-mail: gphong@sejong.ac.kr

\author{
Mi-Jung Choi ${ }^{1}$, Tolibovich Abduzukhurov ${ }^{2}$, Dong Hyeon Park ${ }^{1}$, Eun Jeong Kim ${ }^{3}$, \\ and Geun-Pyo Hong ${ }^{4, *}$ \\ ${ }^{1}$ Department of Food Science and Biotechnology of Animal Resources, Konkuk \\ University, Seoul 05029, Korea \\ ${ }^{2}$ Department of Bioresources and Food Science, Konkuk University, Seoul 05029, \\ Korea \\ ${ }^{3}$ Refrigerator Research of Engineering Division, Home Appliance \& Air Solution \\ Company, LG Electronics, Changwon 51533, Korea \\ ${ }^{4}$ Department of Food Science and Biotechnology, Sejong University, Seoul 05006, \\ Korea
}

\begin{abstract}
This study investigated the effects of deep freezing and storage temperature ($50^{\circ} \mathrm{C},-60^{\circ} \mathrm{C}$, and $-80^{\circ} \mathrm{C}$ ) on the quality and freshness of lamb. To compare the qualities of deep frozen and stored lamb, fresh control and normal freezing conditions $\left(-18^{\circ} \mathrm{C}\right)$ were adopted. As quality and freshness parameters, drip loss (thawing loss and cooking loss), water-holding capacity (WHC), texture profile analysis (TPA), thiobarbituric acid reactive substances (TBARS), and total volatile basic nitrogen (TVBN) were evaluated during 5 months of storage. Temperature influenced the drip loss and WHC, and deep freezing minimized the moisture loss during frozen storage compared to the normal freezing condition. Lamb frozen and stored at deep freezing temperature showed better tenderness than that stored in normal freezing conditions. In particular, lamb frozen at lower than $-60^{\circ} \mathrm{C}$ exhibited fresh lamb-like tenderness. Regardless of temperature, evidence of lipid oxidation was not found in any frozen lamb after 5 months, while TVBN was dependent on the applied temperature. Therefore, this study demonstrated that deep freezing could potentially be used to maintain freshness of lamb for 5 months. From the quality and economic aspects, the freezing and storage condition of $-60^{\circ} \mathrm{C}$ is estimated as the optimum condition for frozen lamb.
\end{abstract}

Keywords lamb, deep freezing, low temperature storage, quality, freshness

\section{Introduction}

Freezing has been recognized as the best preservative method to maintain the quality of foods for long-term storage. Nevertheless, frozen foods show quality deteriorations compared to fresh ones, and this is an inevitable phenomenon. The quality deterioration

(C) Korean Society for Food Science of Animal Resources. This is an open access article distributed under the terms of the Creative Commons Attribution Non-Commercial License (http://creativecommons.org/licences/by-nc/3.0) which permits unrestricted non-commercial use, distribution, and reproduction in any medium, provided the original work is properly cited. 
of frozen foods results from the tissue damage caused by ice crystal formation. To minimize the quality difference between fresh and frozen foods, it is essential to freeze foods quickly and to store them at a low temperature (Kim and Hong, 2016).

Until now, various quick-freezing techniques have been introduced and are commercially available. In the meat industry, up-to-date techniques such as pressure-shift freezing and electromagnetic freezing have been designed to freeze meat instantly, but these techniques also have limitations from technical and economical viewpoints (Choi et al., 2016; Hong and Choi, 2016; Kim and Hong, 2016). A simple method of quick freezing is to decrease the freezing temperature, and the effect of liquid nitrogen on the quality of frozen meat has been widely investigated. However, the occurrence of cold denaturation of protein and cracking on the surface of meat are disadvantages of using liquid nitrogen (Kim et al., 2015). Grujić et al. (1993) reported that meat frozen at a temperature lower than the eutectic point $\left(<-70^{\circ} \mathrm{C}\right)$ had greater drip loss than meat frozen at a relatively higher temperature. Therefore, research regarding the relationship between the freezing conditions and quality of meat has indicated an optimum range of $-18^{\circ} \mathrm{C}$ to $-40^{\circ} \mathrm{C}$, although various deep freezers in which the freezing temperature capacity ranges from $-50^{\circ} \mathrm{C}$ to $-100^{\circ} \mathrm{C}$ are currently available owing to technical development. According to the review of Zhou et al. (2010), $-55^{\circ} \mathrm{C}$ was suggested as the ideal frozen storage temperature of foods.

Recently, domestic consumption of lamb has explosively increased with the popularization of Chinese restaurants. According to the report of Raes et al. (2004), lamb has an ideal fatty acid profile and has a larger amount of long chain polyunsaturated fatty acids than that of beef. This indicates that lamb is a good nutritional source for humans, however, lamb can be easily oxidized during distribution and storage. Therefore, effective preservative methods are necessary for lamb meat, and freezing is favorable to maintain the quality of lamb meat. Although numerous studies have been conducted to evaluate the quality of frozen lamb meat, these reports were focused on the influence of air blast conditions at $-18^{\circ} \mathrm{C}$ (Muela et al., 2010; Muela et al., 2012), and there is no report on the effect of low temperature freezing on the physicochemical properties of lamb. Consequently, this study investigated the effects of deep freezing temperatures (below $-50^{\circ} \mathrm{C}$ ) and storage periods (up to 5 months) on the quality characteristics of lamb meat.

\section{Materials and Methods}

\section{Materials}

Total 77 muscles of chilled female lamb ribs (Ovis aries, 1-year old, 48-h post mortem), a product of Australia, were imported from a local supplier company (Nature's Food Service Co. Ltd., Korea). Australian lamb was imported in refrigerated conditions and delivered by ship for $2 \mathrm{wk}$. After trimming off the visual fat and connective tissue, 25 muscles were used for visual observation and four meat strips $(3 \times 10 \times 3 \mathrm{~cm})$ from remaining each muscle were sampled and vacuumpackaged with poly-nylon pouches. The meat strips were randomly divided by five groups and two strips from each group were inserted thermocouples (k-type) in the geometric center of samples. All samples were then tempered at $2{ }^{\circ} \mathrm{C}$ refrigerator prior to freezing $(\sim 3 \mathrm{~h})$. In this study, chest-type deep freezers (model No. A255WD) of which storage temperature was ranged from $-18^{\circ} \mathrm{C}$ to $-60^{\circ} \mathrm{C}$ were kindly provided by LG electronics (Korea), while NF-400SF freezer (Nihon freezer Co., Japan) was selected to freeze and store lamb at $-80^{\circ} \mathrm{C}$. All chemicals used in this study were analytical grade.

\section{Freezing treatments}

Among five groups, one group (8 strips) was selected as a fresh control of which qualities were analyzed without storage. Remaining four groups (each 48 strips) were respectively frozen and stored for 5 months at four temperatures which were 
classified by normal freezing $\left(-18^{\circ} \mathrm{C}\right)$, deep freezing $\left(-50^{\circ} \mathrm{C}\right.$ and $\left.-60^{\circ} \mathrm{C}\right)$ and eutectic freezing treatment $\left(-80^{\circ} \mathrm{C}\right)$. During freezing, temperature profiles were recorded by connecting thermocouple to a data logger (Yokogawa, Japan). After storage, 8 strips of each treatment were thawed in a $4^{\circ} \mathrm{C}$ refrigerator, until the core temperature of the meat reached $0^{\circ} \mathrm{C}$. Phase transition time was defined by the time from initial freezing point $\left(-1.2^{\circ} \mathrm{C}\right)$ to $-5^{\circ} \mathrm{C}$ in the geometric center of the sample (Yang et al., 2014).

\section{Sampling procedure}

At a given experiment day, 8 strips of each treatment were randomly selected and thawed to determine thawing loss and color. Among them, five strips were cooked to determine cooking loss and texture profile analysis. The remaining three strips were ground together and used for water-holding capacity (WHC), thiobarbituric acid reactive substances (TBARS) and total volatile basic nitrogen (TVBN) analyses.

\section{Thawing loss}

Thawing loss was determined by measuring the weight loss before freezing and after thawing, and expressed as a percentage relative to the initial weight:

Drip loss $(\%)=\frac{W_{1}-W_{2}}{W_{1}} \times 100$

where $W_{1}$ was the initial weight (before freezing) of the sample (g), and $W_{2}$ was the weight of sample after thawing.

\section{WHC}

One gram of the minced sample was wrapped in gauze, subsequently placed into a conical tube, and centrifuged at 3,000×g for $10 \mathrm{~min}$ at $4^{\circ} \mathrm{C}$. The $\mathrm{WHC}$ of samples was calculated as the ratio of the water remaining after centrifugation to the initial water content of the sample, using the following formula:

$\mathrm{WHC}(\%)=\frac{W_{2}}{W_{1}} \times 100$

where $W_{1}$ is initial water content of the sample before centrifugation, and $W_{2}$ is the difference in the water content of the sample after centrifugation.

\section{Cooking loss}

The samples were vacuum-sealed using plastic bags and then cooked in a constant $80^{\circ} \mathrm{C}$ water bath for $30 \mathrm{~min}$. Then, samples were tempered at ambient temperature for $30 \mathrm{~min}$. The samples were weighed before and after the heat treatment. Cooking loss of lamb was expressed as percent weight loss over initial weight, calculated as follows:

Cooking loss $(\%)=\frac{W_{1}-W_{2}}{W_{1}} \times 100$ 
where $W_{1}$ is weight of the sample before cooking and $W_{2}$ is weight of the sample after cooking.

\section{Texture profile analysis}

For texture analysis, the samples used for measuring cooking loss were cut into $10 \times 10 \times 10 \mathrm{~mm}$ cubes. Texture was measured by a CT3 texture analyzer (Brookfield Engineering Labs Inc., USA), and the test parameters were set to: TA3/100 probe, TA/SBA fixture, test speed $2 \mathrm{~mm} / \mathrm{s}$, trigger load $5 \mathrm{~g}$, and compression 70\%, based on Caine et al. (2003).

\section{Color}

Color parameters were determined using a CR-400 Chroma Meter (Konica Minolta sensing, Inc., Japan) directly on the lamb surface. The results are expressed as $L^{*}, a^{*}$, and $b^{*}$ values representing lightness $\left(L^{*}\right)$, redness $\left(a^{*}\right)$, and yellowness $\left(\mathrm{b}^{*}\right)$. The color difference $(\Delta E)$ was calculated as follows:

$$
\Delta E=\sqrt{\left(\mathrm{L}_{1}-\mathrm{L}_{2}\right)^{2}+\left(\mathrm{a}_{1}-\mathrm{a}_{2}\right)^{2}+\left(\mathrm{b}_{1}-\mathrm{b}_{2}\right)^{2}}
$$

where $\mathrm{L}_{1}, \mathrm{a}_{1}$, and $\mathrm{b}_{1}$ are values of the control and $\mathrm{L}_{2}, \mathrm{a}_{2}$, and $\mathrm{b}_{2}$ are the values after thawing. To observe the appearance, the frozen samples were placed on a matte black background and photographed using a camera (EOS 100D, Canon, Japan).

\section{Thiobarbituric acid reactive substances (TBARS)}

Lipid oxidation is an important factor involved in meat rancidity, which can be quantified by the thiobarbituric acid reactive substances (TBARS) following a modified method based on Witte et al. (1970). Five grams of sample was diluted with $45 \mathrm{~mL}$ distilled water and blended for $60 \mathrm{~s}$ on high speed. The mixture was filtered through Whatman No. 1 filter paper. Filtrate $(0.5 \mathrm{~mL})$ was transferred to a test tube followed by addition of $4.5 \mathrm{~mL}$ TBA solution $(0.25 \mathrm{~N} \mathrm{HCl}, 15 \%$ TCA, and $0.375 \%$ TBA reagent). Afterwards, the tube was transferred to a water bath at $95^{\circ} \mathrm{C}$ for $15 \mathrm{~min}$. The sample was centrifuged at $3,000 \times \mathrm{g}$ and $4^{\circ} \mathrm{C}$ for $10 \mathrm{~min}$. After that, $200 \mu \mathrm{L}$ of the supernatant was pipetted into a 96-well plate. Absorbance at $535 \mathrm{~nm}$ was measured using a spectrophotometer (Multiskan ${ }^{\mathrm{TM}}$ GO Microplate spectophotemeter, Thermo Scientific, USA).

\section{Total volatile basic nitrogen (TVBN)}

Total volatile basic nitrogen (TVBN) was determined according to Conway's micro-diffusion method (Conway, 1950). Briefly, the sample $(5 \mathrm{~g})$ was homogenized in $20 \mathrm{~mL}$ of deionized water (DW) in a stomacher bag, using a slap-type homogenizer (WS-400, Hansol Tech. Co., Korea) at a speed set at 9 times/sec for $180 \mathrm{~s}$. The homogenate was filtered through Whatman filter paper Number 1 . Then, the filtrate $(1 \mathrm{~mL})$ was transferred to the outer chamber, and $1 \mathrm{~mL}$ of $0.01 \mathrm{~N} \mathrm{H}_{3} \mathrm{BO}_{3}$ and $100 \mu \mathrm{L}$ of Conway solution $(0.066 \%$ methyl red: $0.066 \%$ bromocresol green, $1: 1$; using $99.99 \%$ alcohol as solvent) as an indicator were added to the inner part of the Conway dish. The Conway unit was sealed immediately after pouring $1 \mathrm{~mL}$ of $50 \% \mathrm{~K}_{2} \mathrm{CO}_{3}$ into the outer chamber. The dish was incubated at $37^{\circ} \mathrm{C}$ for $120 \mathrm{~min}$. The VBN contents were determined following the addition of $0.02 \mathrm{~N} \mathrm{H}_{2} \mathrm{SO}_{4}$ to the inner chamber of the Conway unit and were calculated as $\mathrm{mg} \%$. A blank test was conducted following the same process without adding sample.

$\operatorname{VBN}(\mathrm{mg} \% / 100 \mathrm{~g})=\frac{14.007 \times(a-b) \times f \times 100 \times c}{S}$ 
where $a$ is the titer for sample $(\mathrm{mL}), b$ is the titer for the blank $(\mathrm{mL}), f$ is the factor of $\mathrm{H}_{2} \mathrm{SO}_{4}(0.02 \mathrm{~N}), S$ is the sample weight $(\mathrm{g})$, and $c$ is the dilution ratio.

\section{Statistical analysis}

Completely randomized design was adopted to evaluate the effects of temperature and storage periods on the qualities of lamb meat. Means from three entirely repeated experiments $(n=3)$ were analyzed by one-way analysis of variance (ANOVA) using SPSS statistical software (ver. 22.0). As a post hoc procedure, means were separated by Duncan's Multiple range test at the significant level of $\mathrm{p}<0.05$.

\section{Results and Discussion}

\section{Freezing and thawing profiles}

As expected, the freezing time of the lamb was different depending on the applied freezing temperature (Fig. 1A). The estimated phase transition time of lamb frozen at $-18^{\circ} \mathrm{C}$ was $314 \mathrm{~min}$. In general, quick freezing was defined as $<30$ min to traverse the phase transition of the food center (Yang et al., 2014), hence, the $-18^{\circ} \mathrm{C}$ treatment was classified as slow freezing. Meanwhile, the phase transition times of deep freezing treatment were 26,16 , and 10 min at $-50^{\circ} \mathrm{C},-60^{\circ} \mathrm{C}$, and $-80^{\circ} \mathrm{C}$, respectively. It was expected that tissue damage of frozen lamb would be greater at $-18^{\circ} \mathrm{C}$ treatment than at deep freezing treatments, which might cause quality differences between the two groups.

The thawing time of frozen lamb was similar among all treatments, but samples stored at lower temperatures tended to show longer total thawing times (Fig. 1B). However, phase transition time during thawing of all treatments ranged from 616$647 \mathrm{~min}$, without a significant difference among treatments

\section{Thawing loss, WHC, and cooking loss}

As depicted in Table 1, all treatments showed 1.68\%-2.67\% thawing loss after 2 wk of storage, and lamb stored at lower temperatures showed significantly lower thawing loss $(\mathrm{p}<0.05)$. With storage, all treatments showed a significant increase in thawing loss. Particularly, thawing loss was greater when the lamb meat was stored at a higher temperature $(\mathrm{p}<0.05)$. In frozen meat, thawing loss is an important parameter and an indicator to predict the quality of the frozen meat. Previous reports indicated that decreasing freezing and storage temperature decreased thawing loss of meat (Kim et al., 2015; Kim and
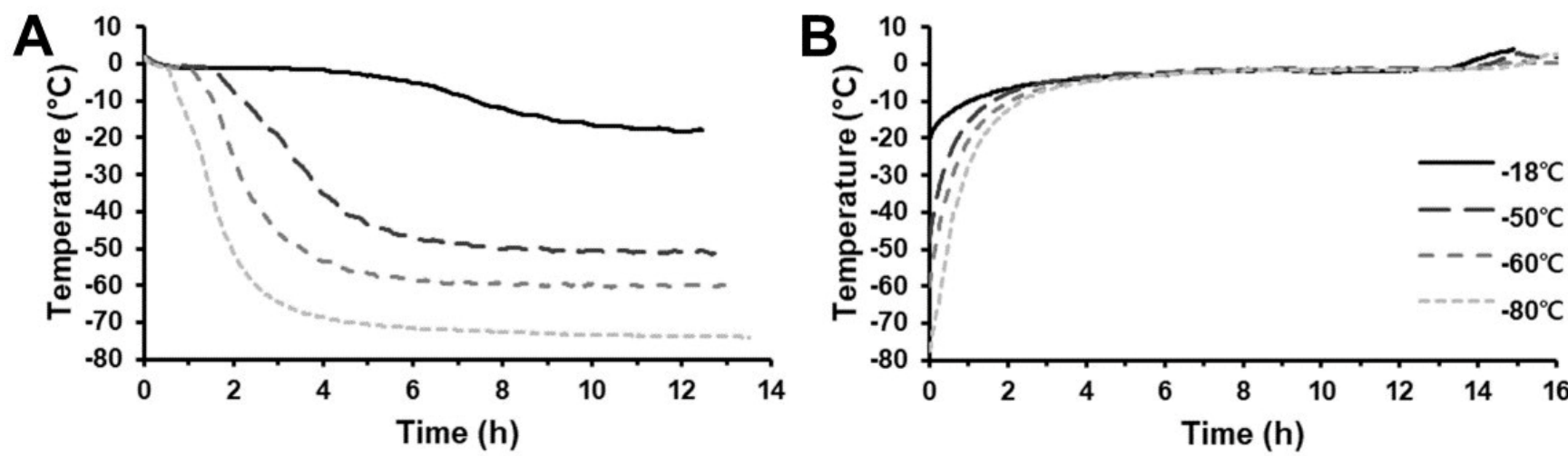

Fig. 1. Time-temperature profiles of lamb meat during freezing (A) and thawing procedures (B). 
Table 1. Changes in the thawing loss, water holding capacity (WHC) and cooking loss of thawed lamb meat depending on various freezing temperatures and different storage periods

\begin{tabular}{|c|c|c|c|c|c|c|c|c|}
\hline \multirow{2}{*}{\multicolumn{2}{|c|}{$\begin{array}{l}\text { Storage } \\
\text { temperature }\left({ }^{\circ} \mathrm{C}\right)\end{array}$}} & \multicolumn{7}{|c|}{ Storage (mon) } \\
\hline & & 0 & 0.5 & 1 & 2 & 3 & 4 & 5 \\
\hline \multirow{4}{*}{$\begin{array}{l}\text { Drip loss } \\
(\%)\end{array}$} & -18 & n.d. & $2.67 \pm 0.11^{\mathrm{eA}}$ & $3.22 \pm 0.16^{\mathrm{deA}}$ & $3.70 \pm 0.36^{\mathrm{dA}}$ & $4.35 \pm 0.54^{\mathrm{cA}}$ & $5.83 \pm 0.32^{\mathrm{bA}}$ & $9.35 \pm 0.25^{\mathrm{aA}}$ \\
\hline & -50 & n.d. & $2.28 \pm 0.11^{\mathrm{dB}}$ & $2.56 \pm 0.30^{\mathrm{dB}}$ & $3.47 \pm 0.24^{\mathrm{cA}}$ & $3.38 \pm 0.14^{\mathrm{cB}}$ & $4.23 \pm 0.23^{\mathrm{bB}}$ & $6.35 \pm 0.39^{\mathrm{aB}}$ \\
\hline & -60 & n.d. & $1.96 \pm 0.09^{\mathrm{eC}}$ & $2.45 \pm 0.23^{\mathrm{dB}}$ & $2.82 \pm 0.13^{\mathrm{bC}}$ & $2.89 \pm 0.22^{\mathrm{cB}}$ & $3.84 \pm 0.14^{\mathrm{bB}}$ & $4.52 \pm 0.17^{\mathrm{aC}}$ \\
\hline & -80 & n.d. & $1.68 \pm 0.12^{\mathrm{dD}}$ & $1.87 \pm 0.13^{\mathrm{cdC}}$ & $2.14 \pm 0.14^{\mathrm{bcC}}$ & $2.02 \pm 0.14^{\mathrm{bcC}}$ & $2.33 \pm 0.23^{\mathrm{bC}}$ & $2.66 \pm 0.24^{\mathrm{aD}}$ \\
\hline \multirow{4}{*}{$\begin{array}{l}\text { WHC } \\
(\%)\end{array}$} & -18 & $87.01 \pm 4.27^{\mathrm{aA}}$ & $75.89 \pm 5.11^{\mathrm{bBC}}$ & $73.10 \pm 2.15^{\mathrm{bcA}}$ & $72.23 \pm 3.03^{\mathrm{bcB}}$ & $70.03 \pm 3.03^{\mathrm{bcB}}$ & $68.41 \pm 2.91^{\mathrm{dC}}$ & $68.04 \pm 0.90^{\mathrm{dC}}$ \\
\hline & -50 & $87.01 \pm 4.27^{\mathrm{aA}}$ & $77.70 \pm 1.87^{\mathrm{bC}}$ & $76.36 \pm 6.59^{\mathrm{bA}}$ & $77.92 \pm 3.65^{\mathrm{bA}}$ & $75.75 \pm 2.69^{\mathrm{bA}}$ & $74.45 \pm 1.35^{\mathrm{bB}}$ & $73.51 \pm 0.98^{\mathrm{bB}}$ \\
\hline & -60 & $87.01 \pm 4.27^{\mathrm{aA}}$ & $80.53 \pm 2.67^{\mathrm{bAB}}$ & $78.30 \pm 3.77^{\mathrm{bA}}$ & $79.92 \pm 0.44^{\mathrm{bA}}$ & $77.03 \pm 1.69^{\mathrm{bA}}$ & $76.30 \pm 0.73^{\mathrm{bAB}}$ & $75.73 \pm 3.08^{\mathrm{bB}}$ \\
\hline & -80 & $87.01 \pm 4.27^{\mathrm{aA}}$ & $84.55 \pm 1.22^{\mathrm{abA}}$ & $80.12 \pm 1.12^{\mathrm{bA}}$ & $80.45 \pm 0.21^{\mathrm{bA}}$ & $80.23 \pm 1.97^{\mathrm{bA}}$ & $80.17 \pm 3.94^{\mathrm{bA}}$ & $79.97 \pm 1.24^{\mathrm{bA}}$ \\
\hline \multirow{4}{*}{$\begin{array}{l}\text { Cooking } \\
\text { loss }(\%)\end{array}$} & -18 & $43.24 \pm 0.76^{\mathrm{abcA}}$ & $41.71 \pm 1.22^{\mathrm{cAB}}$ & $41.59 \pm 0.90^{\mathrm{cA}}$ & $42.55 \pm 0.70^{\mathrm{cA}}$ & $44.69 \pm 0.77^{\mathrm{bcA}}$ & $44.92 \pm 0.78^{\mathrm{aA}}$ & $44.21 \pm 1.70^{\mathrm{aA}}$ \\
\hline & -50 & $43.24 \pm 0.76^{\mathrm{aA}}$ & $40.49 \pm 0.67^{\mathrm{bcB}}$ & $41.99 \pm 1.19^{\mathrm{abA}}$ & $41.32 \pm 1.19^{\mathrm{abAB}}$ & $38.96 \pm 0.74^{\mathrm{cC}}$ & $38.79 \pm 1.90^{\mathrm{cB}}$ & $36.02 \pm 0.97^{\mathrm{dB}}$ \\
\hline & -60 & $43.24 \pm 0.76^{\mathrm{aA}}$ & $42.48 \pm 0.34^{\mathrm{abA}}$ & $41.03 \pm 0.47^{\mathrm{cdA}}$ & $41.81 \pm 0.47^{\mathrm{bcAB}}$ & $40.18 \pm 0.74^{\mathrm{dBC}}$ & $38.78 \pm 0.37^{\mathrm{eB}}$ & $37.45 \pm 1.54^{\mathrm{eB}}$ \\
\hline & -80 & $43.24 \pm 0.76^{\mathrm{aA}}$ & $41.20 \pm 1.01^{\mathrm{abAB}}$ & $40.81 \pm 1.07^{\mathrm{bA}}$ & $40.71 \pm 1.07^{\mathrm{bB}}$ & $41.27 \pm 0.96^{\mathrm{abB}}$ & $40.13 \pm 1.56^{\mathrm{bB}}$ & $36.44 \pm 1.36^{\mathrm{cB}}$ \\
\hline
\end{tabular}

${ }^{\mathrm{a}-\mathrm{e}}$ Means with different letters within the same row (storage periods) are significantly different $(\mathrm{p}<0.05)$.

${ }^{A-D}$ Means with different letters within the same column (temperature) are significantly different $(\mathrm{p}<0.05)$.

n.d., not determined;WHC, water-holding capacity.

Hong, 2016), which was in accordance with this study. Conversely, Ngapo et al. (1999) reported that thawing loss of meat frozen at different rates did not change with extending storage periods, and Farouk et al. (2004) postulated that quick-freezing and very low storage temperature were not necessary. However, the former investigation adopted $-18^{\circ} \mathrm{C}$ to $-20^{\circ} \mathrm{C}$ storage temperature, at which the ice recrystallization would be more easily promoted compared to a lower storage temperature (Martino and Zaritzky, 1989). The latter research selected ultra-quick freezing ( $49.8 \mathrm{~mm} / \mathrm{h}$ of freezing rate) for samples 170 $\mathrm{mm}$ long with $110 \mathrm{~mm}$ diameter. In this case, phase transition time in the meat center would take $\sim 2 \mathrm{~h}$, which was slower than that estimated in this study $\left(26 \mathrm{~min}\right.$ at $\left.-50^{\circ} \mathrm{C}\right)$. Eventually, the frozen lamb kept at lower than $-50^{\circ} \mathrm{C}$ was highly stable during storage compared to that in the freezer maintained at $-18^{\circ} \mathrm{C}$.

Water holding capacity (WHC) of frozen lamb showed a similar pattern to thawing loss of lamb. Excluding $-80^{\circ} \mathrm{C}$ treatment, all freezing treatments exhibited significantly lower WHC than $87.0 \%$ of the control after 2 wk of storage $(p<0.05)$. With extending storage, changes in the WHC of frozen lamb showed different patterns depending on the applied temperature. Lamb stored at $-18^{\circ} \mathrm{C}$ showed a gradual decrease in WHC with storage period and a significant decrease was shown after 3 months of storage $(\mathrm{p}<0.05)$. The WHC of lamb stored at $<-50^{\circ} \mathrm{C}$ also tended to decrease with increasing storage period; however, the differences were not significant during 5 months of storage. Based on the results, it is obvious that quick freezing followed by low temperature storage $\left(<-50^{\circ} \mathrm{C}\right)$ has the potential to minimize tissue damage of lamb meat.

Changes in cooking loss of frozen lamb showed different features depending on applied temperature. Lamb frozen and stored at $-18^{\circ} \mathrm{C}$ tended to show high cooking loss during the storage period while the change was not significantly different. This result was normally in agreement with a previous study (Muela et al., 2010). However, the cooking loss of frozen lamb treated at a low temperature $\left(<-50^{\circ} \mathrm{C}\right)$ was gradually decreased with storage period, and a significant difference was shown after $3-5$ months depending on the applied temperature $(p<0.05)$. The decreased cooking loss by deep freezing treatment is not clearly understood in this study. 
Lamb used in this study was imported at a chilled state for $2 \mathrm{wk}$, reflecting that raw materials had an improved WHC prior to freezing because of aging (Oh et al., 2017). It is likely that the deep-freezing treatments showed an already $2.7 \%-6.4 \%$ thawing loss after 5 months of storage, and thus the cooking loss of frozen stored lamb might have a low cooking loss (Hong et al., 2007). Consequently, the present study demonstrated that the application of deep freezing has a potential advantage to minimize tissue damage of lamb meat, which would be beneficial to maintain the quality of frozen lamb for long storage periods.

\section{Texture profile analysis (TPA)}

Caine et al. (2003) and Ruiz de Huidobro et al. (2005) reported that TPA accounted for sensorial tenderness and juiciness of meat rather than Warner-Bratzler shear force. Hence, the TPA was adopted to compare the tenderness of frozen lamb stored for 5 months (Fig. 2). Hardness in normal freezing treatment $\left(-18^{\circ} \mathrm{C}\right)$ was higher than that of the fresh control $(\mathrm{p}<0.05)$, while those of deep-freezing treatments were not differ from fresh control. Adhesiveness of lamb also showed a similar pattern, but the difference was not significant among treatment groups. Cohesiveness and gumminess of frozen lamb was distinctly lower than the fresh control $(\mathrm{p}<0.05)$, while there was no difference among freezing treatment groups. Springiness of all frozen lamb groups was greater than that of the control $(\mathrm{p}<0.05)$. Chewiness also showed a similar pattern to springiness, whereas lamb frozen at $<-60^{\circ} \mathrm{C}$ showed lower chewiness than that frozen at $>-50^{\circ} \mathrm{C}(\mathrm{p}<0.05)$. Caine et al. (2003) reported that hardness, chewiness, and cohesiveness accounted for the meat tenderness. In this study, the effects of freezing and storage on the tenderness of lamb were highly temperature dependent. As shown in the water binding properties, normal freezing treatment $\left(-18^{\circ} \mathrm{C}\right)$ had a high drip loss after thawing and cooking, which manifested as a film and hard texture compared to the fresh control. Although, the pattern in deep freezing treatments was similar to that of $-18^{\circ} \mathrm{C}$ treatment, and minimizing the difference in drip loss during thawing and cooking would influence the fresh lamb-like tenderness of frozen lamb. Based on the results, deep freezing was effective to maintain textural properties of lamb, and more specifically, freezing and storage at a temperature lower than $-60^{\circ} \mathrm{C}$ would be the optimal condition for lamb meat.

\section{Instrumental and visual color}

All CIE color parameters of frozen lamb were gradually decreased with storage period (Table 2). The lightness (L*) of
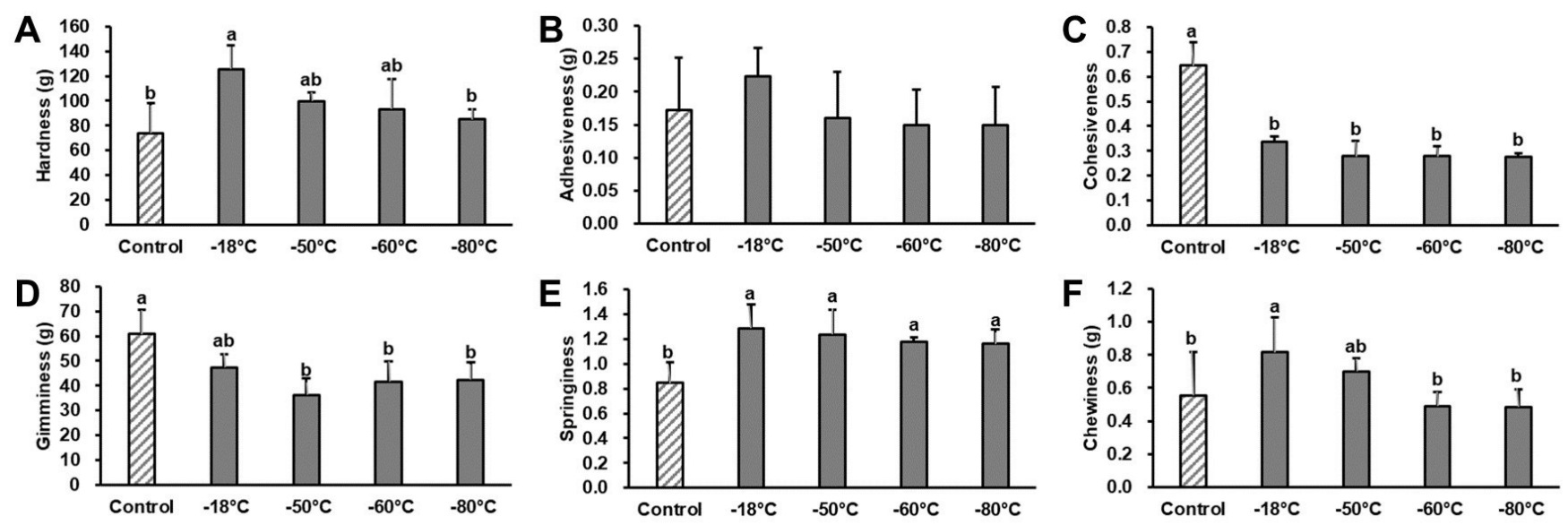

Fig. 2. Textural profiles of lamb frozen and stored at different temperature for $\mathbf{5}$ mon. Vertical bars indicate standard deviations. Means with different letters are significantly different $(p<0.05)$. 
Table 2. Changes in the color of thawed lamb depending on various freezing temperatures and different storage periods

\begin{tabular}{|c|c|c|c|c|c|c|c|c|}
\hline \multirow{2}{*}{\multicolumn{2}{|c|}{$\begin{array}{l}\text { Storage } \\
\text { temperature }\left({ }^{\circ} \mathrm{C}\right)\end{array}$}} & \multicolumn{7}{|c|}{ Storage (mon) } \\
\hline & & 0 & 0.5 & 1 & 2 & 3 & 4 & 5 \\
\hline \multirow[t]{4}{*}{$\mathrm{L}^{*}$} & -18 & $37.57 \pm 1.55^{\mathrm{aA}}$ & $37.40 \pm 0.57^{\mathrm{aAB}}$ & $38.22 \pm 1.33^{\mathrm{aA}}$ & $38.15 \pm 1.43^{\mathrm{aAB}}$ & $37.10 \pm 2.67^{\mathrm{aA}}$ & $38.72 \pm 2.05^{\mathrm{aA}}$ & $35.28 \pm 2.21^{\mathrm{aA}}$ \\
\hline & -50 & $37.57 \pm 1.55^{\mathrm{aA}}$ & $36.26 \pm 1.25^{\mathrm{aB}}$ & $35.58 \pm 1.69^{\mathrm{aB}}$ & $36.00 \pm 1.72^{\mathrm{aB}}$ & $35.18 \pm 1.05^{\mathrm{aA}}$ & $35.53 \pm 1.66^{\mathrm{aB}}$ & $34.88 \pm 1.37^{\mathrm{aA}}$ \\
\hline & -60 & $37.57 \pm 1.55^{\mathrm{abA}}$ & $38.19 \pm 0.82^{\mathrm{abA}}$ & $38.19 \pm 0.61^{\mathrm{aA}}$ & $36.97 \pm 0.82^{\mathrm{abcAB}}$ & $34.99 \pm 1.25^{\mathrm{cA}}$ & $35.01 \pm 1.60^{\mathrm{cB}}$ & $35.96 \pm 2.04^{\mathrm{bcA}}$ \\
\hline & -80 & $37.57 \pm 1.55^{\mathrm{abA}}$ & $38.54 \pm 1.08^{\mathrm{aA}}$ & $38.54 \pm 0.41^{\mathrm{aA}}$ & $39.48 \pm 1.36^{\mathrm{aA}}$ & $36.00 \pm 1.26^{\mathrm{bA}}$ & $36.10 \pm 0.56^{\mathrm{bAB}}$ & $35.69 \pm 0.56^{\mathrm{bA}}$ \\
\hline \multirow[t]{4}{*}{$a^{*}$} & -18 & $18.78 \pm 1.88^{\mathrm{aA}}$ & $16.18 \pm 0.77^{\mathrm{bcA}}$ & $17.92 \pm 1.52^{\mathrm{abA}}$ & $15.89 \pm 0.93^{\mathrm{bcA}}$ & $15.46 \pm 1.61^{\mathrm{bcA}}$ & $14.38 \pm 1.43^{\mathrm{cA}}$ & $14.10 \pm 1.22^{\mathrm{cA}}$ \\
\hline & -50 & $18.78 \pm 1.88^{\mathrm{aA}}$ & $17.47 \pm 1.02^{\mathrm{abA}}$ & $16.99 \pm 1.63^{\mathrm{abA}}$ & $17.61 \pm 1.90^{\mathrm{abA}}$ & $15.08 \pm 1.93^{\mathrm{bA}}$ & $15.31 \pm 0.81^{\mathrm{bA}}$ & $15.00 \pm 0.83^{\mathrm{bA}}$ \\
\hline & -60 & $18.78 \pm 1.88^{\mathrm{aA}}$ & $17.06 \pm 1.44^{\mathrm{abA}}$ & $16.13 \pm 0.51^{\mathrm{bA}}$ & $16.65 \pm 0.99^{\mathrm{abA}}$ & $16.05 \pm 1.38^{\mathrm{bA}}$ & $15.24 \pm 0.54^{\mathrm{bA}}$ & $15.16 \pm 1.33^{\mathrm{bA}}$ \\
\hline & -80 & $18.78 \pm 1.88^{\mathrm{aA}}$ & $16.92 \pm 1.32^{\mathrm{abA}}$ & $18.48 \pm 0.60^{\mathrm{aA}}$ & $18.40 \pm 1.10^{\mathrm{aA}}$ & $16.47 \pm 1.50^{\mathrm{abA}}$ & $15.42 \pm 0.78^{\mathrm{bA}}$ & $14.95 \pm 0.29^{\mathrm{bA}}$ \\
\hline \multirow[t]{4}{*}{$\mathrm{b}^{*}$} & -18 & $7.14 \pm 1.41^{\mathrm{abA}}$ & $6.66 \pm 0.46^{\mathrm{abA}}$ & $7.97 \pm 0.76^{\mathrm{aA}}$ & $6.54 \pm 0.91^{\mathrm{abA}}$ & $6.70 \pm 1.36^{\mathrm{abA}}$ & $6.17 \pm 1.16^{\mathrm{abA}}$ & $5.76 \pm 0.66^{\mathrm{bA}}$ \\
\hline & -50 & $7.14 \pm 1.41^{\mathrm{aA}}$ & $7.12 \pm 0.32^{\mathrm{aA}}$ & $6.87 \pm 1.11^{\mathrm{aA}}$ & $7.48 \pm 1.07^{\mathrm{aA}}$ & $5.65 \pm 1.00^{\mathrm{aA}}$ & $5.94 \pm 0.64^{\mathrm{aA}}$ & $5.99 \pm 0.67^{\mathrm{aA}}$ \\
\hline & -60 & $7.14 \pm 1.41^{\mathrm{aA}}$ & $7.42 \pm 0.86^{\mathrm{aA}}$ & $6.29 \pm 0.59^{\mathrm{abA}}$ & $7.25 \pm 0.92^{\mathrm{aA}}$ & $5.09 \pm 0.89^{\mathrm{bA}}$ & $5.57 \pm 0.31^{\mathrm{bA}}$ & $5.37 \pm 0.47^{\mathrm{bA}}$ \\
\hline & -80 & $7.14 \pm 1.41^{\mathrm{aA}}$ & $7.06 \pm 0.75^{\mathrm{aA}}$ & $7.36 \pm 1.02^{\mathrm{aA}}$ & $7.81 \pm 1.14^{\mathrm{aA}}$ & $6.53 \pm 0.71^{\mathrm{aA}}$ & $5.95 \pm 0.33^{\mathrm{aA}}$ & $5.99 \pm 0.93^{\mathrm{aA}}$ \\
\hline
\end{tabular}

${ }^{a-d}$ Means with different letters within the same row (storage periods) are significantly different $(\mathrm{p}<0.05)$.

$\mathrm{A}, \mathrm{B}$ Means with different letters within the same column (temperature) are significantly different $(\mathrm{p}<0.05)$.

frozen lamb did not differ from the fresh control for 5 months of storage, although deep freezing treatment tended to show a slightly lower $\mathrm{L}^{*}$ than that of $-18^{\circ} \mathrm{C}$ treatment. This would be due to the higher WHC of deep freezing treatment lamb since the moisture bound tightly with protein reflected lesser light than free water (Allen et al., 1998). The decrease in redness ( $\left.a^{*}\right)$ of frozen lamb was faster if lamb was frozen and stored at a relatively high temperature. A significant decrease in $\mathrm{a}^{*}$ of frozen lamb was found after 2 months at $-18^{\circ} \mathrm{C}$ and after 3 months at $-50^{\circ} \mathrm{C}$ and $-60^{\circ} \mathrm{C}$, compared to 4 months at $-80^{\circ} \mathrm{C}$ treatment $(\mathrm{p}<0.05)$. Yellowness $\left(\mathrm{b}^{*}\right)$ of frozen lamb also tended to decrease with storage period, while the differences were not significant from the fresh control. The color change of lamb during storage would be the result of myoglobin oxidation, which could occur during frozen storage (Georgantelis et al., 2007). However, Yang et al. (2014) indicated that the metmyoglobin formation was greatly delayed at temperature lower than $-50^{\circ} \mathrm{C}$.

It was reported that oxidation of myoglobin is responsible for browning of meat during storage (Mancini and Hunt, 2005). Georgantelis et al. (2007) presented that the oxidative browning of the meat product still occurred during frozen storage, but Chin (2017) noted that the discoloration of meat was prevented at $<-50^{\circ} \mathrm{C}$. However, this study showed a significant difference in the color of frozen stored lamb meat, but the difference was not as high as visually detected (Fig. 3). Regardless of temperature, no frozen treatment groups showed any visualized discoloration during 5 months of storage compared to the fresh control. Consequently, the results indicated that freezing was favorable to maintain color stability of the lamb for 5 months of storage. However, it is possible that discoloration could be shown when lamb is stored for more than 5 months.

\section{TBARS and TVBN}

In spite of the high lipid content of lamb, lipid oxidation was effectively prevented by frozen storage for 5 months (Table 3). Initially, fresh lamb showed $0.29 \mathrm{mg} \mathrm{MDA} / \mathrm{kg}$, and the TBARS after freezing treatments ranged from $0.21-0.29 \mathrm{mg}$ MDA $/ \mathrm{kg}$ throughout 5 months of storage. The result was not consistent with Soyer et al. (2010), who reported that chicken meat was oxidized under frozen storage at $-7^{\circ} \mathrm{C}$ to $-18^{\circ} \mathrm{C}$, regardless of temperature. The difference would be due to the storage condition (or packaging) of meat samples. In this study, lamb samples were vacuum-packaged with air-impermeable film prior to freezing, which prevented the contact of air on the surface of the lamb and resulted in stability from lipid oxidation. Because the rate of lipid oxidation is temperature-dependent, frozen storage of lamb meat would successfully 


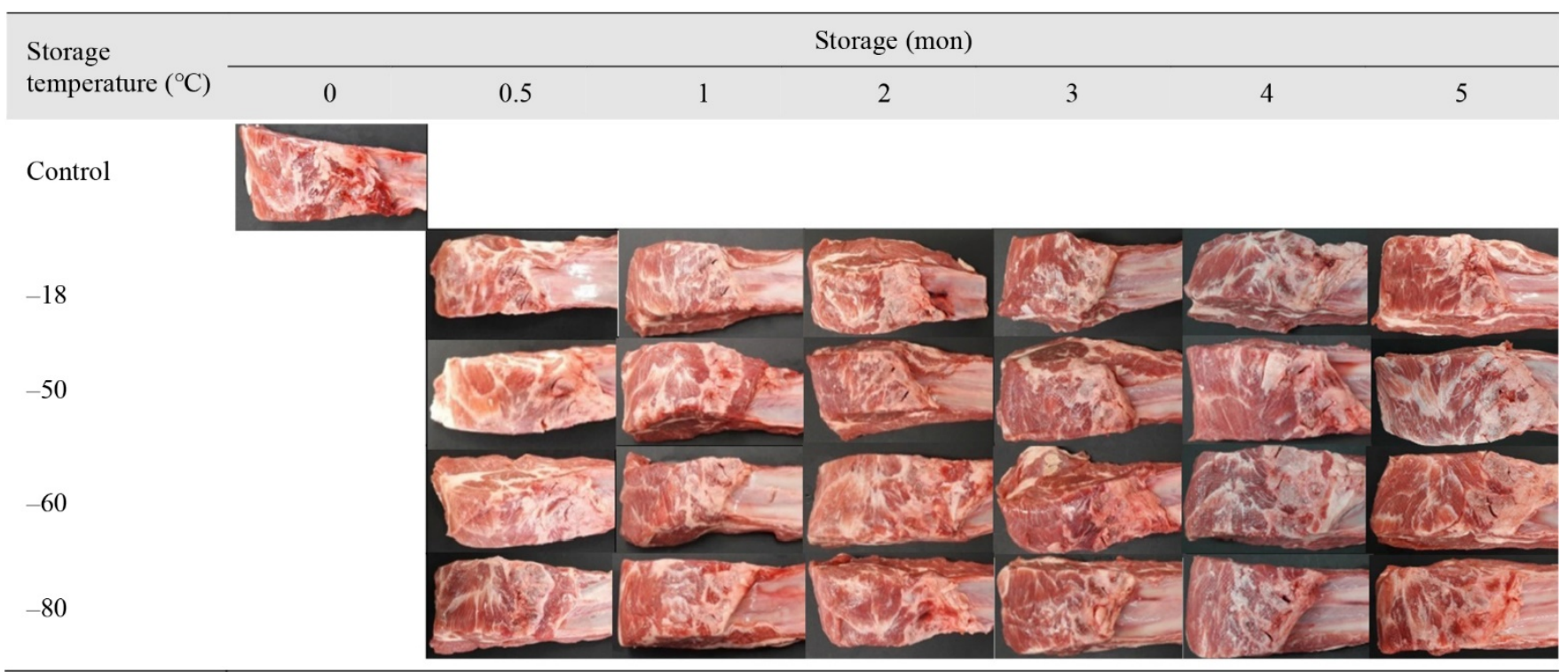

Fig. 3. Changes in the appearance of thawed lamb frozen and stored at different temperatures.

Table 3. Changes in the TBARS and TVBN of thawed lamb depending on various freezing temperatures and different storage periods

\begin{tabular}{|c|c|c|c|c|c|c|c|c|}
\hline \multirow{2}{*}{\multicolumn{2}{|c|}{$\begin{array}{l}\text { Storage } \\
\text { temperature }\left({ }^{\circ} \mathrm{C}\right)\end{array}$}} & \multicolumn{7}{|c|}{ Storage (mon) } \\
\hline & & 0 & 0.5 & 1 & 2 & 3 & 4 & 5 \\
\hline \multirow{4}{*}{$\begin{array}{l}\text { TBARS } \\
(\mathrm{mg} \\
\mathrm{MDA} / \mathrm{kg})\end{array}$} & -18 & $37.57 \pm 1.55^{\mathrm{aA}}$ & $37.40 \pm 0.57^{\mathrm{aAB}}$ & $38.22 \pm 1.33^{\mathrm{aA}}$ & $38.15 \pm 1.43^{\mathrm{aAB}}$ & $37.10 \pm 2.67^{\mathrm{aA}}$ & $38.72 \pm 2.05^{\mathrm{aA}}$ & $35.28 \pm 2.21^{\mathrm{aA}}$ \\
\hline & -50 & $37.57 \pm 1.55^{\mathrm{aA}}$ & $36.26 \pm 1.25^{\mathrm{aB}}$ & $35.58 \pm 1.69^{\mathrm{aB}}$ & $36.00 \pm 1.72^{\mathrm{aB}}$ & $35.18 \pm 1.05^{\mathrm{aA}}$ & $35.53 \pm 1.66^{\mathrm{aB}}$ & $34.88 \pm 1.37^{\mathrm{aA}}$ \\
\hline & -60 & $37.57 \pm 1.55^{\mathrm{abA}}$ & $38.19 \pm 0.82^{\mathrm{abA}}$ & $38.19 \pm 0.61^{\mathrm{aA}}$ & $36.97 \pm 0.82^{\mathrm{abcAB}}$ & $34.99 \pm 1.25^{\mathrm{cA}}$ & $35.01 \pm 1.60^{\mathrm{cB}}$ & $35.96 \pm 2.04^{\mathrm{bcA}}$ \\
\hline & -80 & $37.57 \pm 1.55^{\mathrm{abA}}$ & $38.54 \pm 1.08^{\mathrm{aA}}$ & $38.54 \pm 0.41^{\mathrm{aA}}$ & $39.48 \pm 1.36^{\mathrm{aA}}$ & $36.00 \pm 1.26^{\mathrm{bA}}$ & $36.10 \pm 0.56^{\mathrm{bAB}}$ & $35.69 \pm 0.56^{\mathrm{bA}}$ \\
\hline \multirow{4}{*}{$\begin{array}{l}\text { TVBN } \\
(\mathrm{mg} / 100 \mathrm{~g})\end{array}$} & -18 & $7.14 \pm 1.41^{\mathrm{abA}}$ & $6.66 \pm 0.46^{\mathrm{abA}}$ & $7.97 \pm 0.76^{\mathrm{aA}}$ & $6.54 \pm 0.91^{\mathrm{abA}}$ & $6.70 \pm 1.36^{\mathrm{abA}}$ & $6.17 \pm 1.16^{\mathrm{abA}}$ & $5.76 \pm 0.66^{\mathrm{bA}}$ \\
\hline & -50 & $7.14 \pm 1.41^{\mathrm{aA}}$ & $7.12 \pm 0.32^{\mathrm{aA}}$ & $6.87 \pm 1.11^{\mathrm{aA}}$ & $7.48 \pm 1.07^{\mathrm{aA}}$ & $5.65 \pm 1.00^{\mathrm{aA}}$ & $5.94 \pm 0.64^{\mathrm{aA}}$ & $5.99 \pm 0.67^{\mathrm{aA}}$ \\
\hline & -60 & $7.14 \pm 1.41^{\mathrm{aA}}$ & $7.42 \pm 0.86^{\mathrm{aA}}$ & $6.29 \pm 0.59^{\mathrm{abA}}$ & $7.25 \pm 0.92^{\mathrm{aA}}$ & $5.09 \pm 0.89^{\mathrm{bA}}$ & $5.57 \pm 0.31^{\mathrm{bA}}$ & $5.37 \pm 0.47^{\mathrm{bA}}$ \\
\hline & -80 & $7.14 \pm 1.41^{\mathrm{aA}}$ & $7.06 \pm 0.75^{\mathrm{aA}}$ & $7.36 \pm 1.02^{\mathrm{aA}}$ & $7.81 \pm 1.14^{\mathrm{aA}}$ & $6.53 \pm 0.71^{\mathrm{aA}}$ & $5.95 \pm 0.33^{\mathrm{aA}}$ & $5.99 \pm 0.93^{\mathrm{aA}}$ \\
\hline
\end{tabular}

${ }^{\mathrm{a}-\mathrm{f}}$ Means with different letters within the same row (storage periods) are significantly different $(\mathrm{p}<0.05)$.

${ }^{A-D}$ Means with different letters within the same column (temperature) are significantly different $(\mathrm{p}<0.05)$.

TBARS, thiobarbituric acid reactive substances; TVBN, total volatile basic nitrogen.

inhibit the lipid oxidation and discoloration (Marie, 2015).

Meanwhile, freezing and storage temperature clearly influenced the TVBN of lamb. Comparing to $3.04 \mathrm{mg} / 100 \mathrm{~g}$ of fresh control, all freezing treatments showed higher TVBN $(\mathrm{p}<0.05)$. In particular, the higher the applied temperature, the higher the TVBN of lamb. During storage, all treatments showed a significant increase in TVBN $(p<0.05)$, while the rate of increase in TVBN was profound when the applied temperature was high. It is known that the increase in TVBN is related to the reaction of microbial spoilage. It seems that the reaction can be generated under a temperature of $<-18^{\circ} \mathrm{C}$, since the increased TVBN of frozen samples has also been reported previously (Fan et al., 2009). Although the $-18^{\circ} \mathrm{C}$ treatment showed $7.77 \mathrm{mg} / 100 \mathrm{~g}$ of TVBN after 5 months of storage, the value was lower than the spoiled level $(35 \mathrm{mg} / 100 \mathrm{~g})$ suggested by Connell (1990). Therefore, it was concluded that there was no concern about the lipid oxidation of lamb meat if the meat was not frozen, regardless of temperature, and applying a deep freezer could be a better choice to extend the freshness of lamb meat. 


\section{Conclusions}

In this study, the effects of deep freezing and low temperature storage on the freshness of lamb meat were evaluated. Based on the results, it is clear that decreasing the temperature greatly improved the freshness of lamb meat. In the meat industry, decreasing the temperature for freezing and storage has been limited previously because of economic problems; however, recent advances in storage techniques have enabled the use of deep freezers for labile meats such as lamb. Still, selection of an efficient deep-freezing temperature is necessary for manufacturers and consumers, and this study demonstrated that $-60^{\circ} \mathrm{C}$ was the optimum condition to store frozen lamb meat for 5 months without deterioration of quality and freshness.

\section{Acknowledgements}

This study was financially supported by a grant of Refrigerator Research of Engineering Division, Home Appliance \& Air Solution Company, LG electronics Inc., Korea.

\section{References}

Allen CD, Fletcher DL, Northcutt JK, Russell SM. 1998. The relationship of broiler breast color to meat quality and shelflife. Poult Sci 77:361-366.

Caine WR, Aalhus JL, Best DR, Dugan MER, Jeremiah LE. 2003. Relationship of texture profile analysis and WarnerBratzler shear force with sensory characteristics of beef rib steaks. Meat Sci 64:333-339.

Chin KB. 2017. The science and technology of meat and meat products. Sun Jin Mun Hwa Sa, Seoul, Korea. pp 215-217.

Choi MJ, Min SG, Hong GP. 2016. Effects of pressure-shift freezing conditions on the quality characteristics and histological changes of pork. LWT-Food Sci Technol 67:194-199.

Connell JJ. 1990. Methods of assessing and selecting for quality. In Control of fish quality. $3^{\text {rd }}$ ed. Connell JJ (ed). Springer, Berlin, Germany. pp 122-150.

Conway EJ. 1950. Microdiffusion analysis and volumetric error. $3^{\text {rd }}$ ed. Cosby Lochwood \& Son Ltd., London, UK.

Fan W, Sun J, Chen Y, Qiu J, Zhang Y, Chi Y. 2009. Effects of chitosan coating on quality and shelf life of silver carp during frozen storage. Food Chem 115:66-70.

Farouk MM, Wieliczko KJ, Merts I. 2004. Ultra-fast freezing and low storage temperatures are not necessary to maintain the functional properties of manufacturing beef. Meat Sci 66:171-179.

Georgantelis D, Ambrosiadis I, Katikou P, Blekas G, Georgakis SA. 2007. Effect of rosemary extract, chitosan and $\alpha$ tocopherol on microbiological parameters and lipid oxidation of fresh pork sausages stored at $4^{\circ} \mathrm{C}$. Meat Sci 76:172-181.

Grujić R, Petrović L, Pikula B, Amidžić L. 1993. Definition of the optimum freezing rate-1. Investigation of structure and ultrastructure of beef M. longissimus dorsi frozen at different freezing rates. Meat Sci 33:301-318.

Hong GP, Choi MJ. 2016. Comparison of the quality characteristics of abalone processed by high-pressure sub-zero temperature and pressure-shift freezing. Innov Food Sci Emerg Technol 33:19-25.

Hong GP, Min GS, Ko SH, Shim KB, Seo EJ, Choi MJ. 2007. Effects of brine immersion and electrode contact type low voltage ohmic thawing on the physico-chemical properties of pork meat. Korean J Food Sci An 27:416-423.

Kim KI, Shim JB, Yoo SM, Min SG, Lee SY, Jo YJ, Choi MJ. 2015. Effects of various freezing and thawing techniques on pork quality in ready-to-eat meals. African J Food Sci 9:525-533. 
Kim Y, Hong GP. 2016. Effect of artificial supercooling followed by slow freezing on the microstructure and qualities of pork loin. Korean J Food Sci An 36:650-655.

Mancini RA, Hunt MC. 2005. Current research in meat color. Meat Sci 71:100-121.

Marie CH. 2015. Effect of different freezing/thawing-aging regimens on physicochemical, biochemical characteristics and meat quality attributes of lamb loins. M.S. thesis, Massey Univ., New Zealand.

Martino MN, Zaritzky NE. 1989. Ice recrystallization in a model system and in frozen muscle tissue. Cryobiology 26:138148.

Muela E, Sañudo C, Campo MM, Medel I, Beltrán JA. 2010. Effect of freezing method and frozen storage duration on instrumental quality of lamb throughout display. Meat Sci 84:662-669.

Muela E, Sañudo C, Campo MM, Medel I, Beltrán JA. 2012. Effect of freezing method and frozen storage duration on lamb sensory quality. Meat Sci 90:209-215.

Ngapo TM, Babare IH, Reynolds J, Mawson RF. 1999. Freezing and thawing rate effects on drip loss from samples of pork. Meat Sci 53:149-158.

Oh J, Lee HJ, Kim HC, Kim HJ, Yun YG, Kim KT, Choi YI, Jo C. 2017. The effects of dry or wet aging on the quality of the longissimus muscle from 4-year-old Hanwoo cows and 28-month-old Hanwoo steers. Anim Prod Sci (in press).

Raes K, De Smet S, Demeyer D. 2004. Effect of dietary fatty acids on incorporation of long chain polyunsaturated fatty acids and conjugated linoleic acid in lamb, beef and pork meat: A review. Anim Feed Sci Technol 113:199-221.

Ruiz de Huidobro F, Miguel E, Blázquez B, Onega E. 2005. A comparison between two methods (Warner-Bratzler and texture profile analysis) for testing either raw meat or cooked meat. Meat Sci 69:527-536.

Soyer A, Özalp B, Dalmış Ü, Bilgin V. 2010. Effects of freezing temperature and duration of frozen storage on lipid and protein oxidation in chicken meat. Food Chem 120:1025-1030.

Witte VC, Krause GF, Bailey ME. 1970. A new extraction method for determining 2-thiobarbituric acid values of pork and beef during storage. J Food Sci 35:582-585.

Yang CY, Lee CH, Lee KH, Joo OS. 2014. Low temperature preservation of foods. Shdbooks, Seoul, Korea. pp 249-250.

Zhou GH, Xu XL, Liu Y. 2010. Preservation technologies for fresh meat-A review. Meat Sci 86:119-128. 